\title{
An Analysis of the Candidate Teachers' Beliefs Related to Knowledge, Learning and Teaching
}

\author{
Erdal Bay ${ }^{1}$, Ömer Faruk Vural ${ }^{1}$, Servet Demir ${ }^{1} \&$ Birsen Bağceci $^{1}$ \\ ${ }^{1}$ School of Education, Gaziantep University, Gaziantep, Turkey \\ Correspondence: Erdal Bay, School of Education, Gaziantep University, Gaziantep, Turkey. Tel: \\ 90-532-442-4090. E-mail: erdalbay@hotmail.com
}

$\begin{array}{lc}\text { Received: April 4, } 2014 & \text { Accepted: December 2, } 2014 \quad \text { Online Published: May 27, } 2015 \\ \text { doi:10.5539/ies.v8n6p75 } & \text { URL: http://dx.doi.org/10.5539/ies.v8n6p75 }\end{array}$

\begin{abstract}
Candidate teachers have several beliefs related to their knowledge, learning and teaching. The purpose of this study is to analyze the beliefs of candidate teachers about knowledge, learning and teaching. Candidate teachers were assigned a scale and from the answers "belief points" were obtained based on their attitudes about these three dependent variables. It is investigated whether or not there is a significant difference in candidate teachers' belief points about knowledge, learning and teaching. In addition, this research aims to show to what extent they have these beliefs and predictive among these belief dimensions regardless of variable identification. The relational descriptive method is used in this study. The study was conducted on the 297 primary school candidate teachers selected as subjects of the research in the last year of their education. It is found out that the belief of teaching needs to be constructivist and learning depends on process and efforts are indirectly predicted by the belief on the relativity of knowledge. Similarly, traditional beliefs on teaching are directly and indirectly predicted by the belief that learning depends on effort and ability and the belief in objective and ultimate knowledge. Consequently, it is determined that individuals' beliefs on knowledge, learning and teaching are highly interdependent.
\end{abstract}

Keywords: constructivism, epistemological belief, one-way MANOVA, teacher training

\section{Introduction}

Teachers' beliefs affect their classroom applications (Levin \& Wadmany, 2005). Since teachers' beliefs are influenced by the education that they have had, many researchers have studied the candidate teachers' beliefs and the investigation on the process of change of this belief (Aldrich \& Thomas, 2005; Chai, Teo, \& Lee, 2009). The belief about how knowledge is obtained has been defined as epistemological belief (Hofer \& Pintrich, 1997). The study on measurement of epistemological belief is based on the first studies of Perry (1970) performed with graduate students (Brownlee, 2001). Epistemological belief is determined to be multi-dimensional in the studies conducted in later years (Hofer \& Pintrich, 1997; Schommer, 1990). According to the study of Schommer (1990), (1) The source of information, (2) the accuracy of information, (3) the organization of information, (4) the learning control, and (5) the dimensions of the learning rate have been provided. There are many studies on identification of epistemological belief and whether or not it changes according to different independent variables: a) teachers (Bolden \& Newton, 2008), b) university students (Aldrich \& Thomas, 2005; Chai et al., 2009; Teo, Chai, Hung, \& Lee, 2008) c) grade of school students (Lodewyk, 2007; Schommer-Aikins, Mau, Brookhart, \& Hutter, 2000), and investigations were carried out for these groups according to age and branches.

Studies were conducted on several areas thought to be associated with epistemology. When previously conducted studies are examined, studies on the relationship among the epistemological beliefs with a) the epistemological view of the world (Yilmaz-Tuzun \& Topcu, 2008), b) assessment and evaluation (Bonner \& Chen, 2009), c) the type of motivation, d) self-efficacy (Erdem, Yilmaz, \& Akkoyunlu, 2008), e) learning (Chan, Tan, \& Khoo, 2007; Schreiber \& Shinn, 2003; Zhu, Valcke, \& Schellens, 2008), f) education (Chan et al., 2007), g) academic task performance (Lodewyk, 2007), and h) academic achievement (Lodewyk, 2007) have been carried out.

Epistemological beliefs of candidate teachers have affected their beliefs on learning (Chai et al., 2009; Zhu et al., 2008) and their beliefs on teaching (Chan \& Elliott, 2004). Students' beliefs about knowledge and how knowledge is obtained play an active role in determining the strategies that they will make use of in the learning process (Hofer, 2001). Chai et al. (2009) examined the belief related to learning as effort, process and ability 
sub-dimensions. Individuals' beliefs about teaching are defined in two categories. The first category is seen as the transfer process of interest (traditional) and the second one is considered as the acceleration of the process of students' knowledge creation (constructivist) (Chai et al., 2009). Because of the fact that epistemological belief has a cultural dimension (Hofer, 2008), it must be measured in different cultures and the validity of the scales have to be applied.

The purpose of this study is to analyze the beliefs of final year primary school candidate teachers related to knowledge (relativity/objective and ultimate knowledge), to learning (ability/effort/process) and to teaching (traditional/ constructivist) from different perspectives. From this starting point, answers to the following questions are sought.

1) According to the departmental variables that final year primary school candidate teachers have studied:

a. Is there a significant difference between the points on knowledge and the points on the relativity of knowledge or accuracy of knowledge?

b. Is there a significant difference in the points on the learning related to the belief in whether or not learning depends on effort, process and ability?

c. Is there a significant difference in the points on the belief in whether or not teaching should be traditional or constructivist?

2) What are the candidate teachers' belief total points regardless of variable identification?

3) Do the beliefs about knowledge and learning significantly predict the belief about teaching?

\section{Method}

In the recent study, the relational descriptive method is employed. The study was conducted on the 297 final year primary school candidate teachers that have been studying in Turkish (TR), Mathematics (Math), Science Education (SE) and Elementary School Education (ESE) Departments are selected as the subjects of this study.

\subsection{Data Collection Tool}

"Epistemological beliefs and beliefs about teaching and learning scale" developed by Chai, Teo, and Lee (2009) and later adapted to Turkish by Kıncal, Şahin, and Kartal (2010) is used as a data collection tool. The data collection tool consists of 24 items to measure attitudes to knowledge and learning and 30 items to measure beliefs about teaching. The validity of this measurement tool was previously conducted and its new reliability coefficient is calculated as 0.84 .

\subsection{Data Analysis}

In the data analysis process, one-way MANOVA is applied to determine whether or not program beliefs vary according to the independent variable. Path analysis is conducted to measure predictability among belief dimensions.

\section{Results}

\subsection{Findings Related to the First Sub-Problem}

The analysis of whether there is a significant difference in candidate teachers' beliefs about knowledge, learning and teaching according to the departments they have been studying is given below. 
Table1. The values related to candidate teachers' points on their departments, knowledge, learning and teaching

\begin{tabular}{|c|c|c|c|c|c|c|c|c|}
\hline & & $\begin{array}{l}\text { Turkish } \\
\mathrm{n}=71\end{array}$ & $\begin{array}{l}\text { Math } \\
\mathrm{n}=83\end{array}$ & $\begin{array}{l}\text { Elemantary } \\
\qquad \mathrm{n}=72\end{array}$ & $\begin{array}{c}\text { Science } \\
\mathrm{n}=71\end{array}$ & $\mathrm{~F}$ & Sig & $\begin{array}{l}\text { Mean difference } \\
\text { (Post Hoc test) }\end{array}$ \\
\hline \multirow{2}{*}{$\frac{8}{0}$} & $\begin{array}{l}\text { Relativity of } \\
\text { knowledge }\end{array}$ & 10.45 & 10.62 & 9.83 & 10.63 & 4.074 & .007 & Math. $>$ ESE SE $>$ ESE \\
\hline & $\begin{array}{l}\text { Accuracy of } \\
\text { knowledge }\end{array}$ & 9.19 & 9.91 & 11.47 & 8.39 & 12.564 & .000 & $\begin{array}{l}\mathrm{ESE}>\mathrm{TR} / \mathrm{ESE}>\text { Math } \\
\mathrm{ESE}>\mathrm{SE} / \mathrm{SE}>\text { Math }\end{array}$ \\
\hline \multirow{3}{*}{ } & Ability & 12.30 & 13.42 & 14.98 & 12.90 & 5.723 & .001 & ESE $>$ TR (1.56) \\
\hline & Effort & 34.28 & 33.42 & 33.40 & 33.92 & .586 & .625 & --- \\
\hline & Process & 12.42 & 11.83 & 11.36 & 11.87 & 3.541 & .015 & TR $>$ ESE $(1.06)$ \\
\hline \multirow{2}{*}{ 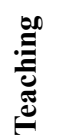 } & Traditional & 47.25 & 46.56 & 50.86 & 47.08 & 3.148 & .025 & ESE > Math. (4.29) \\
\hline & Constructivist & 57.73 & 55.33 & 54.81 & 55.56 & 2.739 & .044 & $\mathrm{TR}>\operatorname{ESE}(2.91)$ \\
\hline
\end{tabular}

Note. Wilks' Lambda $=.784 ; \mathrm{F}_{(1,295)}=3.465 ; \mathrm{p}=.000$.

When the findings in the table are examined, Wilks' Lambda analysis indicates that there is a significant difference in beliefs at least between two groups according to the department variable. Firstly, from the perspective of beliefs on knowledge, the belief points about the relativity of knowledge of candidate teachers from Mathematics Education Department are much higher than the belief points of candidate teachers from Elementary Education Department and similarly, the belief points of candidate teachers from Science Education Department are much higher than those from Elementary School Education Department.

When the points related to whether learning highly depends on process, ability or effort are analyzed, the belief points related to the fact that learning depends on the ability of candidate teachers from Elementary Education Department are higher than the belief points of candidate teachers from Turkish Education Department. There is no significant difference among the groups associated with the perspective of the fact that learning highly depends on effort. The belief points related to the fact that learning depends on process of candidate teachers from the Turkish Education Department are also much higher than those from the Elementary Education Department.

\subsection{Findings Related to the Second Sub-Problem}

The points of candidate teachers on knowledge, learning and teaching regardless of variable identification are intended to be analyzed in this sub-problem. Obtained results are shown below.

Table2. Descriptive statistics related to belief points of candidate teachers on knowledge, learning and teaching

\begin{tabular}{|c|c|c|c|c|c|c|}
\hline & Beliefs & $\mathrm{R}$ & Mean & SD & *Min.-Max. & $* * \%$ \\
\hline \multirow{2}{*}{ Knowledge } & $\begin{array}{l}\text { Relativity of } \\
\text { knowledge }\end{array}$ & 10 & 10.39 & 1.628 & $3-15$ & 62 \\
\hline & $\begin{array}{l}\text { Accuracy of } \\
\text { knowledge }\end{array}$ & 16 & 9.75 & 3.302 & $4-20$ & 36 \\
\hline \multirow{3}{*}{ Learning } & Ability & 20 & 13.41 & 4.157 & $5-20$ & 56 \\
\hline & Effort & 31 & 33.74 & 4.760 & $9-45$ & 69 \\
\hline & Process & 9 & 11.86 & 1.976 & $3-15$ & 74 \\
\hline \multirow{2}{*}{ Teaching } & Traditional & 58 & 47.89 & 9.622 & $17-85$ & 45 \\
\hline & Constructivist & 47 & 55.83 & 6.636 & $13-65$ & 82 \\
\hline
\end{tabular}

Note. $\mathrm{R}=$ Ranges; $\mathrm{SD}=$ Standard Deviation. 
The percentage of teachers' points on the relativity of knowledge is seen as $62 \%$ in the table. In other words, while candidate teachers believe $62 \%$ of the relativity of knowledge, they believe $36 \%$ of the accuracy of knowledge. According to this finding, it can be said that they adopt the relativity of knowledge much more. The fact that candidate teachers adopt the belief that learning depends on process $(74 \%)$ is clearly understood from the table. The percentage of points on the constructivist approach is $82 \%$, whereas the percentage of points on the traditional approach is $45 \%$ in the table. This finding also demonstrates that candidate teachers adopt constructivist approach more than the traditional approach.

\subsection{Findings Related to the Third Sub-Problem}

Path analysis is conducted to determine whether the beliefs on knowledge and learning significantly predict the beliefs on teaching, and results obtained from this analysis are given below.

In path analysis, fit values of the model are measured firstly and these values are shown in the Table 3 . As it can be understood from the Table 3, the constructed model demonstrates compliance with the values well.

Table 3. Path model fit index for the prediction of beliefs on teaching by using beliefs of knowledge and learning

\begin{tabular}{lll}
\hline Fit index & Value & Comments \\
\hline $\mathrm{X}^{2}$ & $12.57(\mathrm{p}>.05)$ & Good \\
RMSEA & 0.046 & Good \\
NNFI & 0.98 & Good \\
CFI & 0.99 & Good \\
SRMR & 0.029 & Good \\
GFI & 0.99 & Good \\
AGFI & 0.96 & Good \\
\hline
\end{tabular}

It is seen in Figure 1 that the belief on the relativity of knowledge indirectly predicts the belief that teaching needs to be constructivist by means of learning-effort and learning-process. It is clearly seen that the belief on the relativity of knowledge contributes to predict mostly (.35) the belief that learning depends on process from sub-dimensions related to learning. The belief on the relativity of knowledge positively contributes to predict the belief that learning depends on process (.33). The belief on the relativity of knowledge does not significantly contribute to predict the belief that learning depends on ability.

On the other hand, the belief on objective/ultimate knowledge directly and indirectly contributes to predict the belief that teaching needs to be traditional (.49). The belief on objective/ultimate knowledge contributes more to predict the belief that learning is based on ability. The belief on objective/ultimate knowledge does not predict the belief that learning depends on process. The belief on objective/ultimate knowledge positively contributes not to predict the belief that learning relies on effort (.23). Authority and being an expert negatively predict the constructivist approach. 


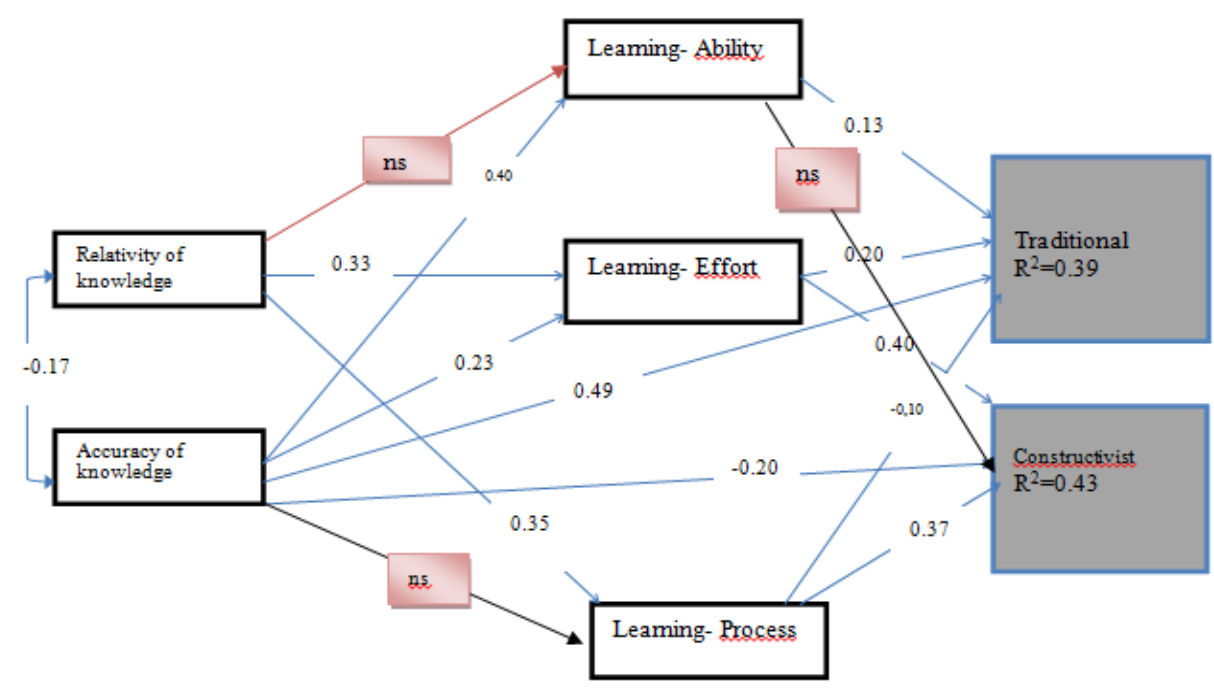

Figure1. Path diagram standard coefficients for the prediction of the beliefs on teaching

In general, it is seen to explain $39 \%$ the variance of related predictability with the belief that learning should be traditional and seen to explain $43 \%$ the variance of related predictability with the belief that learning should be constructivist.

\section{Discussion}

Differentiations according to majors occur in sub-dimensions related to the beliefs about how knowledge is obtained. The beliefs about how knowledge is obtained vary in terms of being specific to individuals as well as to the education processes that they have had (Al-Weher, 2004). In conducted studies, differentiation in some working groups takes place according to working majors of candidate teachers (Chai, Khine, \& Teo, 2006; Eren, 2006) where as there is no differentiation in some groups (Chan, Tan, \& Khoo, 2007). There is a differentiation in majors in the belief that learning depends on process or ability. It can be stated that this differentiation occurs because of their education processes rather than because of their majors. Candidate teachers taking part in this study commonly believe that the knowledge is relative and teaching should be constructivist. Similar results can be found in the academic literature (Aldrich \& Thomas, 2005; Aypay, 2011; Otting, Zwaal, Tempelaar, \& Gijselaers, 2010). There is more belief that process and effort are much more necessary in learning. Due to the fact that there is a relationship between epistemological belief and belief about learning (Schommer-Aikins, Mau, Brookhart, \& Hutter, 2000; Schreiber \& Shinn, 2003) these two sub-dimensions stood out. On the contrary, it was specified that candidate teachers in the study conducted in Hong Kong mostly believed the accuracy of knowledge and ability was more important in learning (Chan \& Elliott, 2000).

The belief that teaching should be constructivist is found to be predicted by the belief that learning depends on process and effort and indirectly by the belief that knowledge is relative. Similarly, it can be said that the belief on traditional teaching is directly and indirectly predicted by the belief that learning depends on effort and ability and the belief on ultimate/objective knowledge. As a result, it is identified that individual beliefs on knowledge, learning and teaching are interdependent. These results (Otting et al., 2010) support the findings of the research. Because this research was conducted in working groups and there were possibly cultural effects (Hofer, 2008), similar research should be conducted in different subject groups to test the conclusions drawn from this research.

\section{References}

Aldrich, J. E., \& Thomas, K. R. (2005). Evaluating constructivist beliefs of teacher candidates. Journal of Early Childhood Teacher Education, 25(4), 339-347. http://dx.doi.org/10.1080/1090102050250408

Al-Weher, M. (2004). The effect of a training course based on constructivism on student teachers' perceptions of the teaching/learning process. Asia-Pacific Journal of Teacher Education, 32(2), 169-185.

Aypay, A. (2011). The Adaptation of the teaching-learning conceptions questionnaire and its relationships with epistemological beliefs. Educational Sciences: Theory and Practice, 11(1), 21-29. 
Bolden, D. S., \& Newton, L. D. (2008). Primary teachers' epistemological beliefs: some perceived barriers to investigative teaching in primary mathematics. Educational Studies, 34(5), 419-432.

Bonner, S. M., \& Chen, P. P. (2009). Teacher candidates' perceptions about grading and constructivist teaching. Educational Assessment, 14(2), 57-77. http://dx.doi.org/10.1080/10627190903039411

Brownlee, J. (2001). Epistemological beliefs in pre-service teacher education students. Higher Education Research and Development, 20(3), 281-291. http://dx.doi.org/10.1080/07294360120108377

Chai, C. S., Khine, M. S., \& Teo, T. (2006). Epistemological beliefs on teaching and learning: a survey among pre-service teachers in Singapore. Educational Media International, 43(4), 285-298.

Chai, C. S., Teo, T., \& Lee, C. B. (2009). The change in epistemological beliefs and beliefs about teaching and learning: a study among pre-service teachers. Asia-Pacific Journal of Teacher Education, 37(4), 351-362.

Chan, K. W., \& Elliott, R. G. (2004). Relational analysis of personal epistemology and conceptions about teaching and learning. Teaching and Teacher Education, 20(8), 817-831. http://dx.doi.org/10.1016/j.tate.2004.09.002

Chan, K., Tan, J., \& Khoo, A. (2007). Pre-service teachers' conceptions about teaching and learning: A closer look at Singapore cultural context. Asia-Pacific Journal of Teacher Education, 35(2), 181-195.

Erdem, M., Yılmaz, A., \& Akkoyunlu, B. (2008). Öğretmen adaylarının bilgi okuryazarlık özyeterlik inançları ve epistemolojik inançları üzerine bir çalışma. Uluslararası Eğitim Teknolojileri Konferansı. Anadolu Üniversitesi. Eskişehir.

Eren, A. (2006). Üniversite öğrencilerinin genel ve alan-odakli epistemolojik inançlarinin incelenmesi. Unpublished doctoral dissertation, Abant İzzet Baysal Üniversitesi, Bolu.

Hofer, B. K. (2001). Personal epistemology research: Implications for learning and teaching. Educational Psychology Review, 13(4), 353-383.

Hofer, B. K. (2008). Personal epistemology and culture. In M. S. Khine (Ed.), Knowing, Knowledge and Beliefs (pp. 3-22). Springer Netherlands. http://dx.doi.org/10.1007/978-1-4020-6596-5_1

Hofer, B. K., \& Pintrich, P. R. (1997). The development of epistemological theories: Beliefs about knowledge and knowing and their relation to learning. Review of Educational Research, 67(1), 88-140. http://dx.doi.org/10.3102/00346543067001088

Kıncal, R., Şahin, Ç. \& Kartal, O. Y. (2010). Determining the change of pre-service teachers' epistemological beliefs and beliefs on teaching and learning. I. Curriculum and Instruction Congress. 13-15 May 2010, Balıkesir, 180-186.

Levin, T., \& Wadmany, R. (2005). Changes in educational beliefs and classroom practices of teachers and students in rich technology-based classrooms. Technology, Pedagogy and Education, 14(3), 281-307. http://dx.doi.org/10.1080/14759390500200208

Lodewyk, K. R. (2007). Relations among epistemological beliefs, academic achievement, and task performance

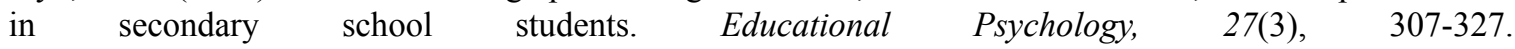
http://dx.doi.org/10.1080/01443410601104080

Otting, H., Zwaal, W., Tempelaar, D., \& Gijselaers, W. (2010). The structural relationship between students' epistemological beliefs and conceptions of teaching and learning. Studies in Higher Education, 35(7), 741-760.

Schommer, M. (1990). Effects of beliefs about the nature of knowledge on comprehension. Journal of Educational Psychology, 82(3), 498. http://dx.doi.org/10.1037/0022-0663.82.3.498

Schommer-Aikins, M., Mau, W. C., Brookhart, S., \& Hutter, R. (2000). Understanding middle students' beliefs about knowledge and learning using a multidimensional paradigm. The Journal of Educational Research, 94(2), 120-127.

Schreiber, J. B., \& Shinn, D. (2003). Epistemological beliefs of community college students and their learning processes. Community College Journal of Research \&Practice, 27(8), 699-709. http://dx.doi.org/10.1080/713838244

Teo, T., Chai, C. S., Hung, D., \& Lee, C. B. (2008). Beliefs about teaching and uses of technology among pre-service teachers. Asia-Pacific Journal of Teacher Education, 36(2), 163-174.

Yilmaz-Tuzun, O., \& Topcu, M. S. (2008). Relationships among preservice science teachers' epistemological 
beliefs, epistemological world views, and self-efficacy beliefs. International Journal of Science Education, $30(1), 65-85$.

Zhu, C., Valcke, M., \& Schellens, T. (2008). The relationship between epistemological beliefs, learning conceptions, and approaches to study: a cross-cultural structural model? Asia Pacific Journal of Education, $28(4), 411-423$.

\section{Copyrights}

Copyright for this article is retained by the author(s), with first publication rights granted to the journal.

This is an open-access article distributed under the terms and conditions of the Creative Commons Attribution license (http://creativecommons.org/licenses/by/3.0/). 